\title{
SOCIAL THEOLOGY: RE-ACTUALIZING CULTURAL VALUES INTO SOCIETY TRANSFORMATION
}

\author{
Nunu Burhanuddin \\ Fakultas Tarbiyah dan Ilmu Kependidikan IAIN Bukittinggi \\ E-mail:boernu@yahoo.com \\ Hardi Putra Wirman \\ Fakultas Ushuluddin Adab dan Dakwah LAIN Bukittinggi \\ E-mail: hardipw@yahoo.com
}

Diterima : 13 Maret 2918

Direvisi : 22 Mei 2018

Diterbitkan : 30 Juni 2018

\begin{abstract}
This paper discusses the issue of theology that is indebted to sciences and technology. Technology, even though imposes a negative impact on theology particulary to those whose faith is still unstable, has strengthened Moslem's belief and does not become a threat. How technology reinforces the faith of Moslem is strongly related to the agenda of reactualization through the praxis activities. The mode of social life should be put on the basis of social transformation in accordance with needs and challenges. The tranformation is closely tied to the development with race structure or buman consciousness with the environment. The modification of buman life in order to achieve such transformation can be actualized through four basic cultural structures: ethical constitution, esthetic, work orientation and the knowledge of technology. The writer concludes that four elements mentioned above determines the success of Islamic civilization for the future life.
\end{abstract}

Keywords: Social theology, faith, good deed, moral constitution, industrial technique

\section{Abstrak}

Tulisan ini membahas masalah teologi yang berutang pada ilmu pengetahuan dan teknologi. Teknologi, meskipun memberikan dampak negatif pada teologi khususnya bagi mereka yang imannya masih tidak stabil, telah memperkuat keyakinan Muslim dan tidak menjadi ancaman. Bagaimana teknologi memperkuat iman umat Islam sangat terkait dengan agenda reaktualisasi melalui kegiatan praksis. Moda kehidupan sosial harus diletakkan di atas dasar transformasi sosial sesuai dengan kebutuhan dan tantangan. Transformasi terkait erat dengan perkembangan dengan struktur ras atau kesadaran manusia dengan lingkungan. Modifikasi kehidupan manusia untuk mencapai transformasi tersebut dapat diwujudkan melalui empat struktur budaya dasar: konstitusi etis, estetik, orientasi kerja dan pengetahuan teknologi. Penulis menyimpulkan bahwa empat elemen yang disebutkan di atas menentukan keberhasilan peradaban Islam untuk kehidupan masa depan.

Kata kunci: teologi sosial, iman, perbuatan baik, konstitusi moral, teknik industri

\section{Introduction}

Taufik Abdullah raised a magnificen statement that when word is upgraded to concept, it becomes meaningfully problematic. While dictionary cannot represent the meaning but it states the point. Determining the meaning is hegemonic working from an interest. ${ }^{1}$ This

${ }^{1}$ Taufik Abdullah, Strategi Kebudayaan untuk Pemberdayaan Masyarakat: Sebuab Sketsa Penjelajahan notion proposed the difficulty to understand a word in utterances. For instance, the word 'teology' means a science of God. ${ }^{2}$ This word presumably came from western intellectual treasure which possess their own sosiologic. In accordance with Mircea Eliade, theology was firstly adopted by Christians related to the

Metodologis, Media Inovasi, Jurnal UMY, No. 2 tahun VII 1996, h. 7

2 Paul Edward, The Encyclopedia of Philoshophy, vol III, Macmillan Pub.Co., New York 1967, h. 348 
connotation of their God and its doctrins, ${ }^{3}$ historically, this discourse was influenced by Hellenis's models. ${ }^{4}$ Theology originally came from the Greek word, theos and logos. In English, theos is synonymous to the word God, while logos is synonymous to word, discourse, thought, and reason. Referring to the lexical meaning, theology can be defined as a rational discourse of God. In the development, it was broadly interpreted because it includes the relationship between God and universe and human beings. ${ }^{5}$ Based on the broad meaning of theology, it today becomes a trend among Moslem society, although Islam has its own term 'Kalam' which is purely Islamic product. According to Afif Muhammad, this tendency emerges from nasty assumption toward Kalam and its discussion that is regarded as merely the science of God. ${ }^{6}$ Whereas 'belief as the main discussion in Kalam is not only related to the meaning of God in 'academic meaning, ${ }^{7}$ it is also related to Moslem historical experiences and daily life.

Theology is more used rather than Kalam may be caused by some reasons. First, Kalam is considered as the science discussing unreachable substance of God. Contextually Salaf clergy deem that the limitation of human mind cannot reach the Greatness of God. ${ }^{8}$ Second, the discussion in Kalam is dialectic-

${ }^{3}$ Mircea Eliade, The Encyclopedia of Religion, Vol. 13, Mac Millan Publishing Company, New York, 1987, h. 455

446

${ }^{4}$ Mircea Eliade, The Encyclopedia of Religion..., $h$.

${ }^{5}$ Lexicon Universal Encyclopedia, Lexicon Publications, Inc. New York, 1990, h. 157

${ }^{6}$ Afif Muhammad, Pengembangan Ilmu Kalam dari Klasik ke Modern: Telaah Sosio-Historis atas Doktrin dan Metode, Mimbar Studi Jurnal Ilmu Agama Islam, No. 2 Tahun XXII, Januari-April 1999, h. 59

7 Yang dimaksud dengan 'akademik' adalah kajian yang menyangkut konsep-konsep dan teori-teori serta ide keagamaan Islam dalam budaya literal. Fazlurrahman menyebut ini sebagai high tradition, sementara yang berkaitan dengan kehidupan sehari-hari disebut low tradition.

${ }^{8}$ Afif Muhammad, Pengembangan Ilmu Kalam..., filosofy-based and includes numerous technical terms, therefore, it is quiet difficult for laymen to understand them. Third, jadal (diaclectic) as the method in Kalam claimed by Abul A'la al-Maududi is often potential to be problem. $^{9}$

The previous reasons indicate that the concept of 'Kalam' needs to be formulated in order to generalize the concept. In other words, the use of term 'theology' is a common phenomenon as the demand from reinterpretation and reactualization of Islamic thoughts treasure, ${ }^{10}$ thus, the writer prefers to use the term 'theology' than 'Kalam' in the title of this article.

Furthermore, when 'theology' is linking up with the word 'social' which relates to society existence, therefore, the meaning of both words become a unit concept that refers to the human historical experiences. In other words, the label 'social theology' implies other topics other than deism such as human transformation. The meaning is believed to be reflection of theology dynamics which is not discussing the deductive character of God, but induce real problems faced by people. The idea of God still becomes mainstream even the focus is directed to globalize theologic view to concrete reality. The discussion of God through dialogue of realities including human issues, religions pluralism, poverty, and human transformation becomes a method and characteristic of contemporary theology. ${ }^{11}$

This article presents a part of contemporary theology problems namely deity taken from social approach through cultural values research. The perception is imbued by Malek Bin Nabi theory, an Aljazair expert,

${ }^{9}$ Abul A'la al-Maududi, Pembaharuan Pemikiran Islam, Pustaka Salman, ITB, Bandung, 1984

${ }^{10}$ Amin Abdullah, Falsafah Kalam Di Era Postmodernisme, Pustaka Pelajar, Yogyakarta, 1995, h. 80

${ }^{11}$ Amin Abdullah, Studi Agama Normativitas atau Historisitas?, Pustaka Pelajar, Yogyakarta, Cet. I, 1996, h. 49 
who proposed the existence of human civilization, turab and time.

\section{Social Theology as the Human Transformation}

The perception of human prestige related to individual and social rights is an undebatable reality. Individual right in society indicates a joint responsibility toward society prosperity, while social right in individual indicates an obligation of each individual toward society. The undeniable right of individual is based on theology principle namely human responsibility to God in the Judgment Day (Yaum al-Hisab). ${ }^{12}$

The individual responsibility arises principle implication in the pattern of human life, a person will not be prosecuted except for what did. One of the consequences is prejudgment that every individual is able to select what will be right or best to be done. ${ }^{13}$

Nurcholis Madjid stated that in praxis order, an individual is not free individual, but he is related to other individuals. Thus, he needs to consider his action to be 'shaleh' (appropriate with individual right and duty). If a person goes across other's line, it may cause chaos or sin in religious term. ${ }^{14}$ This notion is in line with the one proposed by Murtadha Muthahhari, if an individual is potential to have individual sins, members of society are potential as well. ${ }^{15}$ Social problem solving pattern is needed to avoid social sins which includes a social changing to be better or it is known as social transformation. Thus, the writer positions social theology as social transformation.

12 "Wahai manusia! Bertaqwalah kamu sekalian kepada Tuhanmu. Dan waspadalab kamu semua terhadap Hari Kiamat ketika tidak sedikitpun seorang orang tua dapat menolong anaknya dan seorang anak dapat menolong orang tuanya”. QS. Luqman: 33

13 Nurcholis Madjid, Islam Doktrin dan Peradaban, Paramadina, Cet I 1992, h. 564-565

${ }^{14}$ Nurcholis Madjid, Islam Doktrin..., h. 565

${ }^{15}$ Dimitri Mahayana, Antara Dosa Sosial dan Rekayasa Sosial, dalam Rekayasa Sosial, Jalaluddin Rakhmat, Rosda, Cet. I, 1999, h. viii
Moreover, social problem solving or social engineering, as prorposed by Less and Presley, or M.N. Ross called it social planning, or changing management, proposed by Ira Kaufman contains essential refusal toward history determinism and acceptance toward human existence as an entity that does not include only individuals. ${ }^{16}$ Social transformation is a proprietary and care for its own social existence. It comes from an exhortation to form a society as it should be (das sollen), but the reality is what it be (das sein). In other words, transformation is transforming to be better or having a progress in society, as stated by Dawam Rahardjo. ${ }^{17}$

Dawam Rahardjo added that the theory of transformation covers two locus developments, first, the development in 'race structure' or 'awareness' of themselves and the surroundings, proposed by August Comte, second, the development in 'bottom structure' or social and material condition in the human life, proposed by Spencer, Saint Simon, and Karl Mark. ${ }^{18}$

\section{Reunderstanding the meaning of 'Human as Agent of Change'}

According to Malik Bin Nabi, ${ }^{19}$ human world (âlam al-insân) is more salient part of cultural parts other than ground world ('alam at-turâb) and time world ('allam al-waqt). Human will later be able to take the culture into social change to be better.

${ }^{16}$ Jalaluddin Rakhmat, Rekayasa Sosial, Rosda, Cet. I 1999, h. 3-21

${ }^{17}$ M. Dawam Rahardjo, Intelektual Intelegensia dan Perilaku Politik Bangsa: Risalab cendekiawan Muslim, MIZAN, Cet. III 1996, h. 161

${ }^{18} \mathrm{M}$. Dawam Rahardjo, Intelektual Intelegensia..., h. 161

${ }^{19}$ Malik Bin Nabi was born in Constantina, AlJazair, in1905. After graduating from senior high school, he moved to Paris to study about electricity and graduated in 1935. Since young, Malik was used to analyze issues around him. Later, his background education enabled him to raise various world problems that is civilization problems. He saw that the decline of a nation in nature is caused by the problem of its own culture. 
In the context of human change, Malik Bin Nabi presented historical facts in three phases. First, faith period (marbalat al-imân) started from the first day of Al-Qur'an revelation until Siffin war. In this era, spiritual element was so strong, but it decreased at Siffin war. Second, Islamic cultural phase (marbalat as-saqâfah al-Islamiyyah) remarked by maturity in thoughts and understanding of AlQur'an and al-Hadits as the concept. This condition is regarded as the collapse of Muwahhidin dynasty. The third phase is the backwardness and decline period started after the collapse of Muwahhidîn dynasty. Moslem society in the phase of pasca Muwahhidîn are the people who are qâbil li al-isti'mâr (imperialable: ready [to be-] colonized), ${ }^{20}$ more than is colonized (musta'mar).

There is a significant difference between al-isti'mâr (Imperial: colonization) and qâbiliyyat al-isti'mâr (imperialability: ready [to be-] colonized). "A moslem who has nothing to improve or achieve the goals of his life," Malik said, is a colonized moslem. He is categorized into mustad'afin (weak people) those who may God forgives them. ${ }^{21}$

However, "if a Moslem is reluctant to utilize his possession and struggle to improve his life, thus, he is ready to be colonized," Malik added. This means that before being colonized, he himself is ready to be colonized. In conclusion, internal factor has main role to make a person to be as he is. In searching the reason for the decline of moslem, people often direct it to the cruel of western colonizing without awaring that the main cause is coming from themselves.

The analysis from Malik is reinforced by Al-Quran verse which means "Indeed, Allah

${ }^{20}$ Malik Bin Nabi, Wijhat al-'Alam al-Islâmî, Dar al-Fikr al-'Arabî, Damaskus, 1991

21 "Kecuali orang-orang yang lemah, baik laki-laki, perempuan maupun anak-anak, yang tidak menemukan jalan keluar dan tidak mendapatkan petunjuk. Mereka itu, semoga Allah akan memafkannya. Dan Allah sungguh Maha Pemberi maaf dan Maha Pengampun”. Q.S.4: 98, 99 will not change the state of a group except they struggle to change their own state" (Q.S. ar-Ra'd: 11). The words "mâ bi qawmin" in this verse means "the states of a group including decline, progress, and external civilization". The words "mâ bi anfu-sibim" at the end of the verse means "what they own such as thought, the way of thinking, mentality, and progression spirit, or the words "mâ bi anfu-sibim" may have different meaning that is factors or variables in a group. Based on the interpretations, it can be concluded that to go from decline to the progress, Islam people need to change the way of thinking and mentality (as the form of "ma bi anfusibim"). This has become main focus lately to develop Islamic civilization individually or in group.

The change should start from individual (fard) of Moslem to transform it into person (syakhs). The transformation allows a modification of important elements in oneself in relation with his community and develops social tendencies in relation with his society. ${ }^{22}$ According to Malik, person (syakhs) is not only an individual with special characteristics, but also with better ability to produce and as the product of civilization.

Active interdependence between a person (syakhs) and society will shift and stimulate the action of society, and it will affect the action in the journey of society and history. Malik stated that in a person may include two characteristics. First,it is absolute and cannot be influenced by history, but it is natural and a gift from God. Second, it is not absolute, dynamic, and can be influenced by social change and history. The second characteristic, according to Malik, is a social entity. ${ }^{23}$ Malik related the first characteristic (absolute) to anatomical and physiological characteristics which determine the external

${ }^{22}$ Malik Bin Nabi, Wijhat al-' Alam al-Islâmî, Dar al-Fikr al-'Arabî, Damaskus, 1991, h. 55

${ }^{23}$ Fawzia Bariun, "Social Change as Seen by Malik Bennabbi" dalam The American Journal of Islamic Social Sciences, Vol. 8, No. 1, Maret 1991, h. 34 
form of a person. On the other hand, the second characteristic (changeable) is a mental and psychological format formed from social behavior and history's journey. This sociohistoric thought seems to be Malik characteristic. In addition, he added that social action and history' journey is the product of three human elements: hand (yad), heart (qalb) and mind (aql). Every activity is boosted by emotional motivation, mind's guide and consideration, and physical movement.

Every event and historical action cannot be separated from interaction of three worlds: (a) world of figure/ personage (âlam al-asykhâsh), (b) world of mind ('âlam al-afkâr) and (c) world of materials ('alam al-asyyâ'). Although figure/ personage (asy-khâsh) is the main element, Malik considered that world of mind (âlam al-afkâr) plays a dominant role. The wealth of a community is not measured by the materials they own, but ideas they explore.

Furthermore, mistakes in Moslem community especially the Arabic nations producing oil, in accordance with Malik, is that when they receive political independency from their colonial nations, they apply "materials civilization" (al-badlârah asy-syai'iyyah) which based on wealth accumulation and thinking development through interaction with other nations is pushed away.

Malik argued that attempt to develop and bulid a community (Moslem community) may be inspired from Western community. This implies that interaction between two civilizations arises the development of both civilizations. Therefore, the civilization will never develop without any positive interaction between communities. Anyway, Western civilization will never be achieved without interaction with Islamic civilization by adapting positive progressive thought. ${ }^{24}$ The shellacking of Moslem in competing with

${ }^{24}$ Malik Bin Nabi, Hadìts fî al-Binâ' al-Jadìd, AlMaktabah al-'Ashriyyah, Beirut, h. 134-135
Western community in fact is caused by the fault in comparing real needs (adl-dlarûrât alhaqîqiyyah) with side needs (adl-dlarûrât almurayyafab). The confusion affects the world of figure and mind of Moslem people, thus it causes irregular moral and behavior decadence. $^{25}$

Then, Malik concluded that the real problem is not "how to teach Moslem people their faith and belief", but rather "how to recover faith and belief effectivity to create social effect". It can be implied "The problem is not to prove the existence of God, but to remind that the awareness of God existence enable one soul to grow moral power. ${ }^{26}$

Based on the previous explanation, Malik Bin Nabi proposed a modification for awareness, the way of thinking, and social condition through actualization of four cultural basic values: moral constitution (aldustûr al-khuluqî), aesthetics (al-dzৃawq al-jamâlî), logic working (al-manthiq al-'amalî), and industrial technique (ilm al-shinấab). Malik considered that these four elements may represent the elements of society to better change.

\section{Moral Constitution (al-Dustûr al-Khuluqî),} and Aesthetic (al-Dzawq al-Jamâlî)

Discussing 'moral' and ethic does not merely mean a polite matter, but rather basic meaning as a comprehensive concept as starting point of life view on right or wrong, so that, ethic constitution (al-Dustur al-Khuluqi) in a broad meaning covers whole world look and way of life. ${ }^{27}$ According to Karl Barth, as quoted by Nurcholis Madjid, ethic (from ethos) is equal with moral (from mos). Both are phylosophies of customs (sitten). Germany

\footnotetext{
${ }^{25}$ Malik Bin Nabi, Musykilât al-Afkâr, Maktabah 'Ammâr, Kairo, h. 25

${ }^{26}$ Malik Bin Nabi, Wijhat al-' Alam al-Islâmî, Dar al-Fikr al-'Arabî, Damaskus, 1991, h. 55

${ }^{27}$ Nurcholish Madjid, Islam Doktrin..., h. 467
} 
word Sitte (from Germany kuna, situ) means moda (mode) human behavior, a constancy of human action. Thus, in general ethic and moral is philosophy, science, or discipline about human behavior mode or human action constancies. ${ }^{28}$

Referring to the meaning above, the moral constitution proposed by Bin Nabi ir related with human moral force in response to change of modern life. This means that as its duty moral constitution is expected to bind up cultural parts so that all of them interweave and characterize the culture, on the other side, these bounds seems enable to create the character of the way of life and behavior of individual.

Malik asserted that there is a special relationship between moral principle and aesthetics, ${ }^{29}$ in fact, it is an organic interaction and has an important social function because the interactions determine cultural characteristic and civilization direction profoundly when they are attached to life pattern and individual behaviors. The organic relationship is obvious when it is focused on the aesthetic, which grows a civilization, but it is ended in 'a great fire' caused by a man like Nero or a woman like Messaline. On the other hand, a culture prioritizing moral principles created a civilization with static and petrified deity, and ended by the beackwardness led by tarekat commander. ${ }^{30}$

Further investigation will show that ethic principle and aesthetic affects other life

${ }^{28}$ Nurcholish Madjid, Islam Doktrin..., h. 468

${ }^{29}$ Orientasi estetika yang digagas Malik bin Nabi diilhami dari sabda Nabi Saw.: "Tidak akan masuk surga orang yang di dalam kalbunya terdapat sebiji sawi kesombongan." Seseorang bertanya kepada Nabi, "bagaimana jika ada laki-laki yang senang jikea baju dan terompahnya bagus?" Nabi menjawab, "Sesunggubnya Allah itu indah dan mencintai keindahan. Yang namanya sombong adalab menolak kebenaran dan menghalangi manusia dari kebenaran." (Sahih Muslim, I: 193, hadis ke-137; Lihat juga, Musnad Ahmad bin Hambal, I: 299, dengan redaksi dari Muslim).

${ }^{30}$ Malik Bin Nabi, Syurût al-Nabdhah, Dar elFikr, Damaskus, Cet. Iv, 1987 areas including patrilineal and matrilineal family structure, ideology 'art for art' which prioritises aesthetic and ideology 'bound literature' which prefaces ethic values to political method issues. In this political concept, how glory skyscrapers seen as aesthetic motive, while 'society prosperity' is unifinished. Therefore, it is obvious that ethic values and aesthetic affects the direction of purposed transformation (change).

\section{Work Orientation (al-Manthiq al-'Amalî)}

Work orientation or work ethos often raises hot talk when it is connected to the view of social transformation. The issue is a fact that no nation with Moslem citizen becomes developed country. A discussion about the growth level in Islamic countries can mean discussing an unreached thing. ${ }^{31}$ The class of unemployed people in Islamic countries becomes a class to be questioned about the social transformation. Is there any discussion about work orientation is Islam? or Is there concept of Qur'an which motivate people to work? If the answer to the question is reverse to the reality in Islamic society in which poors and low class people gather, so that no reason needs to be questioned. The concept of AlQur'an is fascinating in declaring the criteria of 'al-mukminun' with work requirement. Every word 'Amanu' (people who have faith) is accompanied by 'wa 'amil al-shalibat' (and people who do good deeds). ${ }^{32}$

Muhammad 'Âbid Al-Jâbirî stated that the values of good deeds is based on faith and faith itself (in Islam) is not oriented to Allah because $\mathrm{He}$ is the Great Rich but to human. ${ }^{33}$ So that, it is not uncommon that the word "alÎmân" in Al-Qur'an is attached to the word 'al'amal al-shâlib' by relating to syarat and masyrut,

\footnotetext{
${ }^{31}$ Malik Bin Nabi, Syurût al-Nahdhah..., h. 110

32QS. Al-'Ashr: 1-3

${ }^{33}$ Muhammad 'Âbid Al-Jâbirî, Al-'Aql alAkblâqî al-'Arabî, Beirut: Markaz Dirâsât al-Wihdah al-
} 'Arabiyyah, 2004 h. 593 
that is faith requirement to form good deeds. The repeatedly concept of faith and good deeds reflects that good deeds is a representative of Al-Qur'an ethical values or real Islamic ethical values. ${ }^{34}$

Moreover, the synergy between faith and good deeds emerges religious term 'taqwa' as the top character of perfect person. In many verses, taqwa (godfearing) relates to the relationship between Mu'min people and Allah (babl min Allâh) and between Mu'min people each other (babl min al-Nâs). In significance, faith does not reflect godfearing except following by good deeds. Al-Jâbirî added that if godfearing is the main value in Islam as the religion, good deed is the main value in character reflecting Islamic ethic, so that it is called good deeds ethic. ${ }^{35}$ Ironically, this glory concept is not followed by the real action by the people. Thus, what is the real problem of this 'lazy' culture?

Nurcholish Madjid said, if it is allowed to see the case only in the tenet side - the meaning is taken from the concept of AlQuran--, therefore, a classic controverion raises about the human capability in determining work (Qadariyyah) or human forcing to unable to determine their own work (Jabariyyah). Both tenets raise an issue that Moslem people opt to fatalic Jabariyyah, especially after the domination of al-Asy'ari tenet. This assumption can be seen from its concept about kasb in the book Jawhar alTawhid, which is considered as the reason for fatalism: "Wa indana li "l-abd-i kasb-un kullifa wa lam yakunm mu'atstsiran fa 'l-ta'rifa, Fa laysa majuran wa la ikbtiyaran wa laysa kullan yaf'alu ikbtiyaran Fa in yutsibna fa bi mabdl-i "l-fadl'l-i $W a$ in yu' adzdrib fa bi mahdl-i "l-adl-i". (For us, the servants abandoned kasb, but the kasb will not

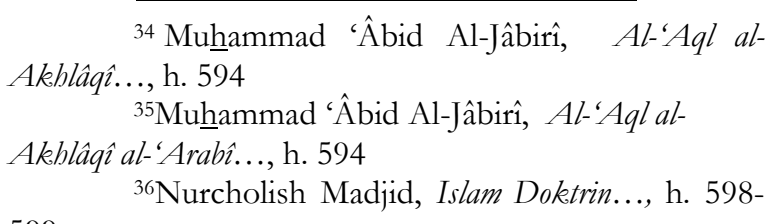

${ }^{34}$ Muhammad 'Âbid Al-Jâbirî, Al-'Aql alAkhlâqî..., h. 594

${ }^{35}$ Muhammad 'Âbid Al-Jâbirî, Al-'Aql alAkblâqî al-'Arabî..., h. 594

${ }^{36}$ Nurcholish Madjid, Islam Doktrin..., h. 598-

affect, so that, people are not forced or free or even act freely. If He bestows reward, it is His own generous, and if He tortures, it is only for his justice).

In response to this tenet, Ibn Taymiyyah critically commented this theory as irrational theory, thus, he categorized it as the miracle of Kalam science. Then, Ibn Taymiyyah straightened the theory by saying; (no solution for people to get out of His certainties, but people may choose the correct or wrong thing. Thus, it is not forced without a will, but rather he intends by his own will). ${ }^{37}$ Although this is a sharp and rational critic, only minority class adopted it. Hence, work orientation of Moslem people is influenced by fatalis theology system. This is the reason for Malik Bin Nabi to call Islam people to do self-introspection through motivation and work education. At last, it is a must that methodological orientation about working is the first prerequirement before providing pecial facilities for life.

\section{Industrial Technique (ilm al-Shinâ'ah)}

The industrial issue covers technologies, professions, abilities, and applications of many sciences. The main problem is how to create individual to carry risalah of history. It is impossible to generate as if smart person or layman of technology because they are cotrolled by instinct not vision and mind, ${ }^{38}$ as the water flows through damaged turbine. Hodgson supported this by saying that the development of era is the result of transmutation or change through science and its application by technology. Hence, the positive attitude toward technology and industry through faith system will complete the process involving inter dynamics which supports to be better. Islamic country is not a child asking for importing everthing from

${ }^{37}$ Nurcholish Madjid, Islam Doktrin..., h. 598-

${ }^{38}$ Ibn Khaldun, Muqaddimah, Kairo: Lajnah alBayan al-'Arabî, 1965 h. 170 
other countries without any effort to 'create something'. How people achive a transformation, when a need for needles still be fulfilled by importing from China.

\section{Conclusion}

The writer asserts that the faith system in Islam is supported by science and technology. In other words, the fact that universe is originated from sometime in the past in which is created from nothing (creatio ex nibillo) indicates the existence of God supported by modern scientific theory. William Craig, a Barkeley modern phylosophist stated that Kalam cosmologic argument guides us to the declaration of one Khâliq in the universe without any change both before and after the universe created.

This cosmologic proving is expected to be substantial materials for Moslem that Islamic theology is supported by science and technology. Therefore, Islam people need to welcome the technology as faith strengthen, not threat. The reactualization of this principle should be done through variation of practical activities later on.

\section{REFERENCES}

Abdullah, Taufik, (1996) Strategi Kebudayaan untuke Pemberdayaan Masyarakat: Sebuah Sketsa Penjelajahan Metodologis, Media Inovasi, Jurnal UMY, No. 2 tahun VII

Abdullah, Amin, (1995) Falsafah Kalam Di Era Postmodernisme, Yogyakarta: Pustaka Pelajar

Abdullah, Amin, (1996) Studi Agama Normativitas atan Historisitas?,

Yogyakarta: Pustaka Pelajar

Al Jâbirî, Muhammad 'Âbid, (2004) Al-'Aql al-Akblâqî al-'Arabî, Beirut: Markaz Dirâsât al-Wihdah al-'Arabiyyah
Al Mawdûdî, Abul A’la (1984), Pembaharuan Pemikiran Islam, Bandung: Pustaka Salman

Bariun, Fawzia, (1991) "Social Change as Seen by Malik Bennabbi" dalam The American Journal of Islamic Social Sciences, Vol. 8, No. 1, Maret 1991

Bin Nabi, Malik, (1991) Wijhat al-'Alam alIslâmî, Damaskus: Dar al-Fikr al-'Arabî

Bin Nabi, Malik, (1991) Hadîts fì al-Binấ alJadìd, Beirut: Al-Maktabah al-'Ashriyya

Bin Nabi, Malik, (1991) Musykilât al-Afkâr, Kairo: Maktabah 'Ammâr

Bin Nabi, Malik, (1987) Syurût al-Nabdhah, Damaskus: Dar el-Fikr

Edward, Paul, (1967) The Encyclopedia of Philoshophy, vol III, New York: Macmillan Publishing Company

Eliade, Mircea, (1987) Eliade, The Encyclopedia of Religion, Vol. 13, New York: Mac Millan Publishing Company

Ibn Khaldun, (1965) Muqaddimah, Kairo:

Lajnah al-Bayan al-'Arabî

Lexicon Universal Encyclopedia, (1990)

Lexicon Publications, Inc. New York

Madjid, Nurcholis Madjid, (1992) Islam Doktrin dan Peradaban, Jakarta: Paramadina

Muhammad, Afif, (1999) Pengembangan Ilmu Kalam dari Klasik ke Modern: Telaah Sosio-Historis atas Doktrin dan Metode, Mimbar Studi Jurnal Ilmu Agama Islam, No. 2 Tahun XXII

Rahardjo, M. Dawam, (1996) Intelektual Intelegensia dan Perilaku Politik Bangsa: Risalah cendekiawan Muslim, Bandung: MIZAN

Rakhmat, Jalaluddin, (1999) Rekayasa Sosial, Bandung: Rosda 